\title{
APATITE FROM AN OLIVINE PYROXENITE OF THE CANAÃ VALLEY, ESPÍRITO SANTO, BRAZIL: FISSION-TRACK AGE DETERMINATION AND CONFINED TRACK LENGTH MEASUREMENTS IN ORDER TO ESTABLISH AN INTERNAL STANDARD
}

\begin{abstract}
ARIADNE DO CARMO FONSECA ${ }^{1}$, MARIA LAURA BALESTRIERI ${ }^{2}$, GIULIO BIGAZZI ${ }^{3}$ AND PIO NORELLI ${ }^{3}$
ABSTRACT We present the first results of fission-track age determinations and natural confined track length measurements in apatite crystals of an olivine pyroxenite from the Canaã Valley, Espírito Santo, Brazil. This apatite was chosen for its high abundance in the rock and also for its high uranium content. Confined track length measurements were performed by three different analysts, whereas fission-track ages corresponding to two different irradiations were determined by two analysts. Confined track length distributions as well as ages showed good reproducibility. The characteristics of this apatite (its abundance in the rock and the relatively large number of confined tracks) make it a very promising internal standard which experienced a more complex thermal history in comparison with the volcanic apatite international age standards. The fission-track age of around $95 \mathrm{Ma}$ of the apatite sample from the olivine pyroxenite is consistent with the age interval $65-110$ Ma previously measured by Fonseca and Poupeau (1984), Fonseca (1989) and Fonseca et al. (1992) in the Ribeira Belt. This age interval corresponds to the basaltic and alkaline volcanic activities related to the opening of the Atlantic Ocean.

Keywords: fission-track dating, apatite, olivine pyroxenite, Canaã Valley, Espírito Santo, Brazil
\end{abstract}

ABSTRACT We present the first results of fission-track age determinations and natural confined track length measurements in apatite crystals of an olivine pyroxenite from the Canaã Valley, Espírito Santo, Brazil. This apatite was chosen for its high abundance in the rock and also for its high uranium content. Confined track length measurements were performed by three different analysts, whereas fission-track ages corresponding to two different irradiations were determined by two analysts. Confined track length distributions as well as ages showed good reproducibility. The characteristics of this apatite (its abundance in the rock and the relatively large number of confined tracks) make it a very promising internal standard which experienced a more complex thermal history in comparison with the volcanic apatite international age standards. The fission-track age of around 95 Ma of the apatite sample from the olivine pyroxenite is consistent with the age interval 65-110 Ma previously measured by Fonseca and Poupeau (1984), Fonseca (1989) and Fonseca et al. (1992) in the Ribeira Belt. This age interval corresponds to the basaltic and alkaline volcanic activities related to the opening of the Atlantic Ocean.

INTRODUCTION The use of reference samples allows to test and improve accuracy of analytical methodologies. In fission-track dating, the Subcommission on Geochronology of the International Union of Geological Sciences (I.U.G.S.) established that age standards should form the basis of all system calibrations (Hurford 1990). This is the only way to compare measurements performed by different analysts and/or different methodologies. The Subcommission on Geochronology of the I.U.G.S., the Fish Canyon Tuff apatite and the Durango apatite recommends only two apatite samples as standard. The first is distributed by C.W. Naeser, from the U.S. Geological Survey, and only very small aliquots are supplied. The Durango apatite is a mineral for collection. Another additional standard, distributed by A.J. Gleadow (La Trobe University, Melbourne, Australia) is the apatite from Mount Dromedary Intrusive Complex.

Due to poor thermal stability of fission tracks in apatite, this mineral phase yields the formation age of the rocks only in case of fast cooling after their emplacement (in practice, in case of volcanic rocks). On the contrary, when a rock experienced after its emplacement temperatures higher than around $60^{\circ} \mathrm{C}$ during a time not negligible compared to its age, the fission-track age that one can measure is a minimum age. In practice, there is a temperature interval, approximately between $60^{\circ} \mathrm{C}$ e $110^{\circ} \mathrm{C}$, named partial annealing zone, in which fission tracks are only partially retained. The amount of track length reduction increases with the temperature, and above $110^{\circ} \mathrm{C}$ the tracks are totally unstable.

Considering that the spontaneous fission of ${ }^{238} \mathrm{U}$ occurs at a constant rate during time, each track experienced a peculiar part of the thermal history of the rock. Using the track length distribution it is possible to decipher the time - temperature path of the rock since it cooled below $110^{\circ} \mathrm{C}$. For this reason, the apatite fission-track analysis (AFTA), combination of age determination and track length measurement, turned to be an efficient tool for thermochronological studies.
Therefore, accuracy of track length measurements is also important and the use of standard samples may greatly contribute to their optimization. A reference sample-set should include apatites that experienced different thermal histories, including those more complex than the simple fast cooling corresponding to the those from the Fish Canyon Tuff and Durango. In this paper we present the first results from apatite chosen for its abundance in the host rock and its high uranium fission-track density, to adopt it as an internal standard for reproducibility tests and for comparisons of measurements performed by different analysts and/or with different equipment.

GEOLOGICAL SETTING The apatite used for this study was extracted from an olivine pyroxenite, outcropping in the Canaã Valley, near the village of Santo Antônio, Espírito Santo (Fig. 1). This olivine pyroxenite belongs to the Pre-Cambrian Unit $\in$ Yolpx, including the group of late to post transcurrent acid and basic intrusions in the Colatina map, published by the Companhia de Pesquisa de Recursos Mineriais - CPRM (Company of Research of Mineral Resources; Tuller 1993). This rock outcrops as a small circular body (about 1 $\mathrm{Km}^{2}$ ). To the north, west and east this grey-greenish coloured body is in contact with the regional aluminum gneisses, whereas to the south

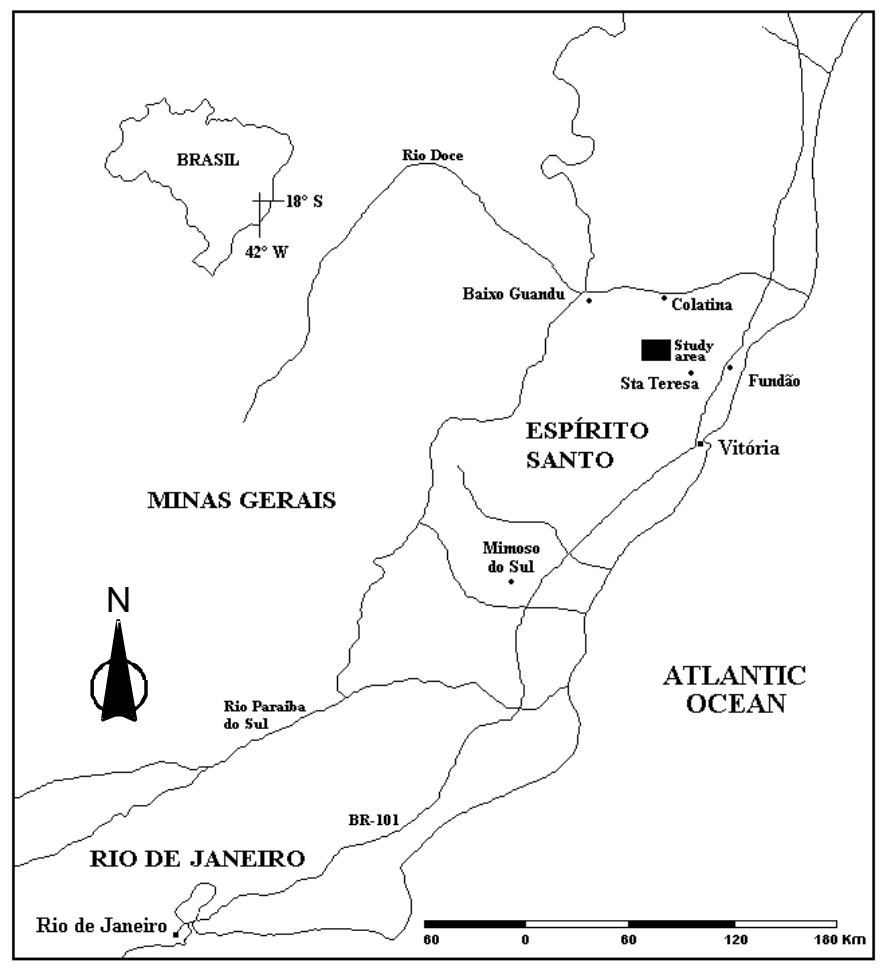

Figure 1 - Location of the study area. 
it is in contact with the Santa Tereza hedenbergitic gneiss. The rock is isotropic, medium grained and it is cut by quartz and feldspar veins. It does not show significant deformation, although this rock is involved in a big folded structure, probably produced by its own emplacement.

Mineralogical and petrographic determinations As a detailed mineralogical and petrographic study of the olivine pyroxenite from the Canaã Valley is not the aim of this paper, only a short account is given here. The rock consists of olivine, clino- and orthopyroxene, hornblende, mica, plagioclase, apatite and opaque minerals. By means of X-ray diffraction, olivine was determined as fayalite, orthopyroxene as ferrosilite, clinopyroxene as augite and the mica as phlogopite. Analysis of polished sections revealed that the present opaque minerals are pyrrhotite, pentlandite, chalcopyrite and chalcocite.

The mineralogical and petrographic determinations were performed in the X-Ray Diffractometry and Fluorescence Laboratory of the Department of Geology in the Federal University of the Rio de Janeiro.

SAMPLE PREPARATION Separation of the various mineral phases was performed sequentially by crushing (jaws), quartering, grinding, washing and drying, and sieving $(100,160,250 \mathrm{~mm}$ and remainder)

For each fraction the following procedure was carried out: (1) magnet for extraction of pyrrhotite and pentlandite; (2) Frantz magnetic separator for extraction of the following mineral phases: phlogopite, clinopyroxene + hornblende, orthopyroxene + hornblende, olivine and diamagnetic minerals; and (3) heavy liquid (sodium politungstate) for separation of the light (plagioclase) and heavy (apatite) phases.

An aliquot of the apatite population was heated $\left(2\right.$ hours at $\left.500^{\circ} \mathrm{C}\right)$ to erase natural fission tracks accumulated during geological time. This aliquot was divided into two fractions that were separately irradiated in the Lazy Susan facility of the Triga Mark II nuclear reactor of the University of Pavia, Italy. After irradiation, three fractions of the apatite grain population (one containing natural tracks, for measurement of spontaneous track lengths and areal density, and two irradiated, for induced track areal density determination) were mounted in epoxy, polished and etched $\left(\mathrm{HNO}_{3} 5 \%\right.$ for 45 seconds at room temperature).

EXPERIMENTAL RESULTS Fission-tracks commonly used for thermochronological studies based on track length distributions are those wholly contained within the apatite crystals, etched through fractures or other tracks. These are named "confined tracks". Therefore, the number of confined tracks is rather limited compared to tracks intercepting the polished surface. As the confined tracks yield their full length, even a small number of them may be enough to inform on thermal histories. However, at least 100 lengths are measured, when possible. This number is commonly adequate for representing a length distribution.

In this work we used an instrument which is alternative to the more popular system digital tablet - microscope equipped with light camera This is a Leitz Orthoplan microscope coupled to Microvid accessory. The image produced by the lens of the microscope is superimposed to the image of a small monitor. The mouse of the computer drives a small reference cross that has to be placed at the end of the object to be measured. A click of the mouse and the displacement of the cross to the other end of the object produce a line segment whose length is displayed on the monitor. This system is very practical and quick, and has the advantage that segments corresponding to determinations made
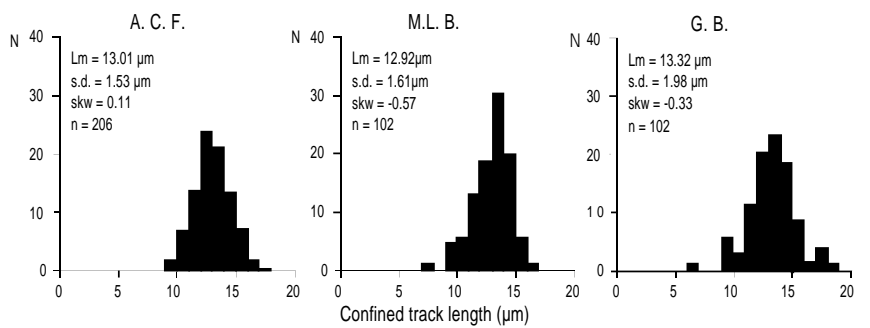

Figure 2 - Confined track length distributions (normalized to 100) measured by three analysts in the Canã̃ Valley apatite.

Lm: mean length; s.d.: standard deviation; skw: skewness coefficient; $N$ : number of measurements.

previously remain on the screen. In this way it is possible to verify each measurement.

Confined track lengths measured by three analysts (A. C. F, M.L. B. and G. B.) are shown in figure 2. The first two analysts obtained very similar results and the third analyst (G. B.) determined slightly longer mean length with higher standard deviation. However, the difference can not be regarded as significant.

Two analysts (A. C. F. and G. B.), using a Leitz Orthoplan microscope and a Jena Jenaval microscope, respectively made the age determinations. Results are shown in Table 1. Reproducibility of age determinations turned to be excellent, as age values obtained by different analysts with different equipment and using different irradiated fractions of the sample are very consistent.

FISSION-TRACK AGE The fission-track age of around $95 \mathrm{Ma}$ of the apatite sample from the olivine pyroxenite is consistent with the age interval 65-110 Ma previously measured by Fonseca and Poupeau (1984), Fonseca (1989) and Fonseca et al. (1992) in the Ribeira Belt. This age interval corresponds to the basaltic and alkaline volcanic activities related to opening of the Atlantic Ocean. During Gondwana fragmentation, the continental margins of Africa and Brazil experienced continuous uplift related to lithosphere doming, and voluminous extrusion occurred.

The upward movement and the related erosion processes brought deep-seated rocks to more superficial crustal levels. In this way, metamorphic and igneous rocks of the Pre-Cambrian basement were exposed to lower pressure-temperature conditions.

The brittle behavior of these rocks that produced structural lows and highs during the tectonic activity related to the opening of the ocean, indicates that they already cooled, relatively to their formation temperature, when they were brought to the surface. During the upward movement, the Pre-Cambrian basement rocks cooled below the $110^{\circ} \mathrm{C}$ isotherm and fission-track retention started. Consequently, the fission-track analysis of apatite from the present continental margins allowed studying the timing and characteristics of their exhumation.

A comparable apatite fission-track age interval (65-110 Ma) had been determined for the oriental margins of the Atlantic Ocean, in southwestern Africa (Haack 1976).

To extract more information on the thermal history of the host rocks of the apatite from the Canaã Valley, we applied the Monte Trax computer modeling (Gallagher 1995). This software yields the timetemperature paths most consistent with the measured fission-track analytical data.

Table 1 - Fission-track age determination of an apatite sample from an olivine pyroxenite from the Canaã Valley, Espírito Santo, Brazil.

\begin{tabular}{|ccccccccc|}
\hline Analyst & $\begin{array}{c}\rho_{\mathrm{S}}\left({\mathrm{x} 10^{6}}^{6}\right) \\
\left(\mathrm{cm}^{-2}\right)\end{array}$ & $\mathrm{n}_{\mathrm{S}}$ & $\begin{array}{c}\mathrm{s}_{\mathrm{S}} \\
(\%)\end{array}$ & $\begin{array}{c}\Phi \\
\left(\mathrm{cm}^{-2}\right)\end{array}$ & $\rho_{\mathrm{I}}\left({\left.\mathrm{x} 10^{6}\right)}\left(\mathrm{cm}^{-2}\right)\right.$ & $\mathrm{n}_{\mathrm{I}}$ & $\begin{array}{c}\mathrm{s}_{\mathrm{I}}^{\prime} \\
(\%)\end{array}$ & $\begin{array}{c}\text { Age } \pm 1 \sigma \\
(\mathrm{Ma})\end{array}$ \\
\hline A. F. C. & 5.586 & 5,062 & 1.9 & $2.52 \times 10^{15}$ & 7.352 & 6,662 & 1.8 & $94.6 \pm 2.5$ \\
& & & & $2.42 \times 10^{15}$ & 7.050 & 3,194 & 2.5 & $94.6 \pm 3.0$ \\
G. B. & \multirow{2}{*}{4.984} & \multirow{2}{*}{3,165} & 2.9 & $2.52 \times 10^{15}$ & 6.459 & 2,461 & 2.7 & $96.1 \pm 3.8$ \\
& & & & $2.42 \times 10^{15}$ & 6.624 & 2,524 & 2.9 & $89.8 \pm 3.7$ \\
\hline
\end{tabular}




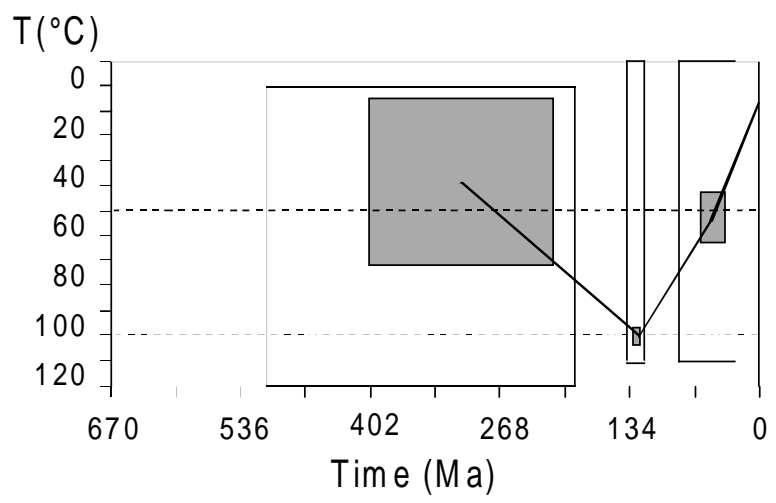

N

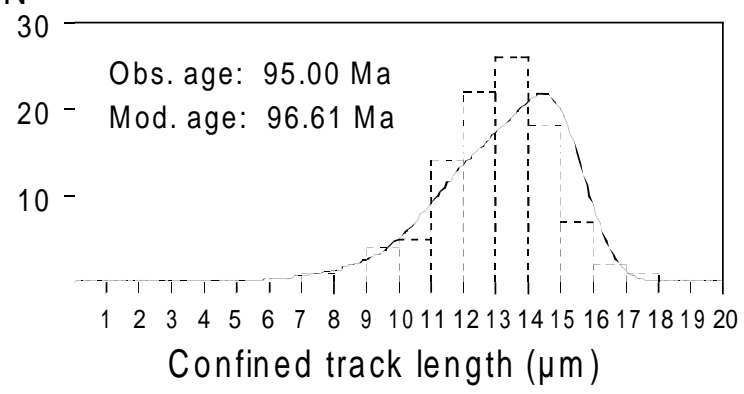

Figure 3 - Thermal history produced by application of Monte Trax modeling (Gallagher, 1995). For the confined track length distribution, we have chosen the mean histogram of those shown in Fig. 2. The continuous line represents the best fit of the experimental results. The large boxes represent the limits imposed for choosing time-temperature points during the modeling procedure. The gray boxes represent the $\pm 1 \sigma$ limits of the weighted mean of the timetemperature paths produced by Monte Trax. The horizontal dashed lines are the limits of the partial annealing zone. Obs. age: observed age; Mod. age: age produced by the modeling procedure.

According to Gallagher et al. (1994), who analyzed apatite samples from the continental margin of south-eastern Brazil, we selected four time-temperature points, including the present surface mean temperature of $20^{\circ} \mathrm{C}$. For the remaining three points, a wide temperature inter- val was chosen, between surface temperature up to that corresponding to apatite fission-track total annealing. For the first point, time was left free to vary between 500 and 200 Ma. For the second, the time interval is rather narrow (between 120 and $140 \mathrm{Ma}$ ), since it represents the age of the eruption of the Paraná Basin basalts. A post-eruption point follows, in the time span between 100 and $20 \mathrm{Ma}$.

The genetic algorithm procedure was used, with generation of 50 time-temperature paths for each of 10 iterations. The thermal history that best fits with the experimental results is shown in figure 3 . The wide limits of the box, weighted mean of the iterations $\pm 1 \sigma$, which represents the first point, indicate that this procedure did not constrain the history prior to around $130 \mathrm{Ma}$. The best fit time-temperature path of figure 3 suggests that the rocks experienced temperatures close to those corresponding to fission-track total annealing during eruption of the basalts and beginning of the sea-floor spreading of the South Atlantic Ocean. Rocks cooled by at least ca. $80^{\circ} \mathrm{C}$ during the last 130 Ma.

CONCLUSIONS The apatite from the Canaã Valley olivine pyroxenite has a high track areal density useful for testing counting strategies. This sample allows measuring, in a relatively short time, a large number of confined track lengths. Population method fissiontrack ages as well as confined track length distributions showed good reproducibility. The thermal history deciphered by the apatite fissiontrack analysis was well consistent with geological information. Therefore, we consider this apatite, which experienced a more complex history than simple fast cooling, as a promising additional reference to compare determinations made by different analysts and/or using different equipment as well as to test various computer programs used in apatite fission-track analysis.

Considering its high track density, this apatite may also be useful to test alternative dating technique named External Detector Method.

Acknowledgments To Maria Cristina Wiedemann (Rio de Janeiro) who supplied the olivine pyroxenite sample, for her help with opaque mineral determination, Isabel Pereira Ludka for X-ray Diffractometry analyses and Julio Cesar Mendes for his help with petrographic studies. This research was partially supported by a grant of the Brazilian National Council of Research and Scientific Development (CNPq).

\section{References}

Balestrieri M. L., Bigazzi G., Fonseca, A. C. and Norelli P. 1996. Sistemi di misura di lunghezze al microscopio: in confronto. Plinius, 15: 267-270

Carpenter B. S. and Reimer G. M. 1974. Calibrated glass standards for fission track use. Nat. Bur. Stds. Spec. Publ., 260: 49p.

Fonseca A. C. and Poupeau G. 1984. Datações por traços de fissão em algumas rochas metamórficas na cidade do Rio de Janeiro. Anais do XXXIII Congr. Bras. Geol.: 2321-2332.

Fonseca A. C. 1989. Fragmentação do Gondwana: seu registro na Faixa Ribeira. I Simpósio de Geologia do Sudeste, Caderno de Resumos: 184-185.

Fonseca A. C., Bigazzi G. and Cordani U. G. 1992. A datação pelo método dos traços de fissão de apatita e titanita de algumas rochas metamórficas da região entre Cabo Frio e Búzios. An. XXXVII Congr. Bras. Geol., São Paulo: 190-191.

Gallagher K. 1995. Evolving temperature histories from apatite fission-track data. Earth Planet. Sci. Lett., 136: 421-435.

Gallagher K., Hawkesworth C. J. and Mantovani M. S. M. 1994. The denudation history of the onshore continental margin of SE Brazil inferred from apatite fission track data. J. Geophys. Res., 99: 18,117-18,145.
Haack, V. U. 1976. Rekonstruktion der Abkühlungeschichte des Damara-Orogens in Südwest-Africa mit Hilfe von Spaltspuren-Altern. Geol. Runds., Bd. 65: 967-1001.

Hurford A. J. W. 1990. International Union of Geological Sciences. Subcommission on Geochronology. Reconmmendation for the standardization of fission track dating calibration and data reporting. Nucl. tracks Radiat. Meas., 17: 233-236.

Reimer G. M., Storzer D. and Wagner G. A. 1970. Geometry factor in fission track couting. Earth Planet. Sci.Lett., 9: 401-404.

Tuller M.P. 1993. Texto explicativo da folha SE.24-Y-C-VI, Colatina. In: M.P. Tuller (org.) Programa Levantamentos Geológicos Básicos do Brasil, DNPM/CPRM, Brasília. $163 \mathrm{pp}$

Contribution IGC-008 Received January 21, 2000 Received January 21, 2000
Accepted for publication April 21, 2000 